\title{
Purinergic junctional transmission and propagation of calcium waves in cultured spinal cord microglial networks
}

\author{
Max R. Bennett • Vlado Buljan • Les Farnell • \\ William G. Gibson
}

Received: 7 June 2007 / Accepted: 13 August 2007 / Published online: 23 October 2007

(C) Springer Science + Business Media B.V. 2007

\begin{abstract}
In order to elucidate the mechanisms of purinergic transmission of calcium $\left(\mathrm{Ca}^{2+}\right)$ waves between microglial cells, we have employed microphotolithographic methods to form discrete patterns of microglia that allow quantitative measurements of $\mathrm{Ca}^{2+}$ wave propagation. Microglia were confined to lanes $20-100 \mu \mathrm{m}$ wide and $\mathrm{Ca}^{2+}$ waves propagated from a point of mechanical stimulation, with a diminution in amplitude, for about $120 \mu \mathrm{m}$. The number of cells participating in propagation also decreased over this distance. $\mathrm{Ca}^{2+}$ waves could propagate across a cell-free lane from one microglia lane to another if this distance of separation was less than about $60 \mu \mathrm{m}$, indicating that propagation involved diffusion of a chemical transmitter. This transmitter was identified as ATP since all $\mathrm{Ca}^{2+}$ wave propagation was blocked by the purinoceptor antagonist suramin, which blocks $\mathrm{P}_{2} \mathrm{Y}_{2}$ and $\mathrm{P} 2 \mathrm{Y}_{12}$ at relatively low concentrations. Antibodies to $\mathrm{P} 2 \mathrm{Y}_{12}$
\end{abstract}

M. R. Bennett ( $₫)$

The Neurobiology Laboratory, Department of Physiology, The University of Sydney, New South Wales, 2006, Australia e-mail:maxb@physiol.usyd.edu.au

M. R. Bennett · V. Buljan

The Neurobiology Laboratory, Institute for Biomedical Research,

Department of Physiology, The University of Sydney,

New South Wales, 2006, Australia

L. Farnell · W. G. Gibson

The School of Mathematics and Statistics,

The University of Sydney,

New South Wales, 2006, Australia showed these at very high density compared with $\mathrm{P} 2 \mathrm{Y}_{2}$, indicating a role for $\mathrm{P} 2 \mathrm{Y}_{12}$ receptors. These observations were quantitatively accounted for by a model in which the main determinants are the diffusion of ATP released from a stimulated microglial cell and differences in the dissociation constant of the purinoceptors on the microglial cells.

Keywords Calcium waves • Microglia • Propagation • Purines · Transmission

\section{Introduction}

Microglia give a calcium $\left(\mathrm{Ca}^{2+}\right)$ transient in mixed cultures of microglia and astrocytes, following mechanical stimulation of a single astrocyte $[1,2]$. This transient in the microglia is dependent on the release of ATP by the astrocytes [1]. However, nothing is known about the mechanism of transmission of a $\mathrm{Ca}^{2+}$ signal between microglial cells that allows for propagation of a $\mathrm{Ca}^{2+}$ wave in populations of microglia [3]. In the absence of neurons, $\mathrm{a} \mathrm{Ca}^{2+}$ wave in astrocytes propagates for hundreds of microns from a point of mechanical stimulation (e.g., $[4,5])$. It remains to be seen whether a $\mathrm{Ca}^{2+}$ signal can be transmitted between microglia in such a way that there is propagation of a $\mathrm{Ca}^{2+}$ wave.

The $\mathrm{Ca}^{2+}$ waves in astrocytes, when initiated at a point in a culture, can jump cell-free gaps of different widths formed by scraping away cells $[4,6]$. Such $\mathrm{Ca}^{2+}$ waves propagate across these gaps with a delay that increases with gap width until this width reaches about $150 \mu \mathrm{m}$, when such propagation fails. More recent research has used micropatterned arrays of astrocytes in which lanes of cells about $110 \mu \mathrm{m}$ wide alternate with 
cell-free lanes about $40 \mu \mathrm{m}$ wide $[4,5]$. If a $\mathrm{Ca}^{2+}$ wave is initiated by mechanical stimulation in an astrocyte in just one lane it propagates both along the lane as well as transversely across the cell-free lanes into the adjacent astrocyte lanes with a delay of about $10 \mathrm{~s}$. These observations support the idea that the transmission of $\mathrm{Ca}^{2+}$ waves between astrocytes involves the release of a diffusible substance. The question of whether this wave is transmitted between microglia by a diffusible substance has not been addressed. It is known that microglia collecting in the vicinity of a stab wound express connexin CX43 and that these cells are coupled by such connexins in vitro under the control of certain cytokines [7]. However, given the relative low density of resting microglia in the brain compared to that of astrocytes [8-10], it seems unlikely that connexins are used by microglia in normal circumstances to transmit $\mathrm{Ca}^{2+}$ waves. We have therefore used micropatterned arrays of microglia to ascertain if the $\mathrm{Ca}^{2+}$ wave can propagate across cell-free regions, thus indicating that a diffusible substance is involved in transmission. As shown below, this turns out to be the case.

Microglia possess $\mathrm{P}_{2} \mathrm{X}_{7}, \mathrm{P}_{2} \mathrm{Y}_{1}, \mathrm{P}_{2} \mathrm{Y}_{2 / 4}, \mathrm{P}_{2} \mathrm{Y}_{6}, \mathrm{P}_{2} \mathrm{Y}_{12}$, $\mathrm{P}_{2} \mathrm{Y}_{13}$ and $\mathrm{P} 2 \mathrm{Y}_{14}$ purinoceptors [11-14] with $\mathrm{P} 2 \mathrm{Y}_{12}$ receptors and $\mathrm{P} 2 \mathrm{X}_{7}$ receptors unique to microglia, at least in the hippocampus [15]. There is evidence that some microglia cells possess predominantly $\mathrm{P} 2 \mathrm{X}$ receptors and others predominantly P2Y receptors [16]. $\mathrm{P}_{2} \mathrm{X}_{7}$ receptors on microglia are involved in apoptosis, transcription and microvesicle shedding [17]. Activation of $\mathrm{P}_{2} \mathrm{X}_{7}$ receptors can lead to the release of proinflammatory cytokines, such as $\mathrm{TNF} \alpha[18,19]$. $\mathrm{P}_{2} \mathrm{Y}_{1}$ and $\mathrm{P}_{2} \mathrm{Y}_{2 / 4}$ receptors are involved in the release of the cytokine IL-10 that acts to markedly reduce the release of the pro-inflammatory cytokines [20]. Most $(85 \%)$ resting microglia respond to ATP with a $\mathrm{Ca}^{2+}$ transient [21] as a consequence of an action of ATP on $\mathrm{P} 2 \mathrm{X}$ and $\mathrm{P} 2 \mathrm{Y}$ receptors $[11,14]$. The activation of $\mathrm{P} 2 \mathrm{X}$ receptors leads to an influx of calcium ions whereas the activation of $\mathrm{P} 2 \mathrm{Y}$ receptors releases calcium from internal stores [21-26]. Microglia can also release ATP using in part ATP-binding cassette (ABC) proteins, such as P-glycoproteins (mdr $1 \mathrm{a}$ and mdr 1b) and multidrug resistant associated proteins (mrp1 and mrp4; [27]). Taken together, these observations on the action of ATP on purinergic receptors possessed by resting microglia suggest the hypothesis that the transmission of $\mathrm{Ca}^{2+}$ waves between microglia is due to ATP, and this we have investigated.

The experimental work is supplemented by calculations using a theoretical model of extracellular communication in cellular networks, originally developed for astrocytes [28], and here modified for microglia.

\section{Methods}

The experimental methods for immunohistochemistry, mechanical stimulation of leading to $\mathrm{Ca}^{2+}$ waves in cells, application of drugs, recording $\mathrm{Ca}^{2+}$ waves and seeding cells into lanes were the same as that previously described [5]. The purification of microglia started when plated mixed glia culture from SpragueDawley rat pup spinal cord formed a confluent monolayer (usually between 1 and 2 weeks). The culture was shaken at $200 \mathrm{rpm}$ for $1 \mathrm{~h}$ at $37^{\circ} \mathrm{C}$ using rotating shaker (IKA-Vibrax-VXR). During shaking, the astrocytes remained adhered to the poly-D-lysine coating whereas the microglia and oligodendrocytes detached from the astrocyte monolayer. Immediately after shaking, the medium containing the detached cells was transferred to a $15-\mathrm{ml}$ centrifuge tube and centrifuged for $5 \mathrm{~min}$ at $500 \mathrm{rpm}$. The supernatant was discarded and the pellet was resuspended in $1 \mathrm{ml}$ DMEM and triturated. Cell density was adjusted by adding fresh DMEM (typically 1-2 ml) after cell trituration and $300 \mu \mathrm{L}$ of the cell suspension was pipetted onto each coverslip containing

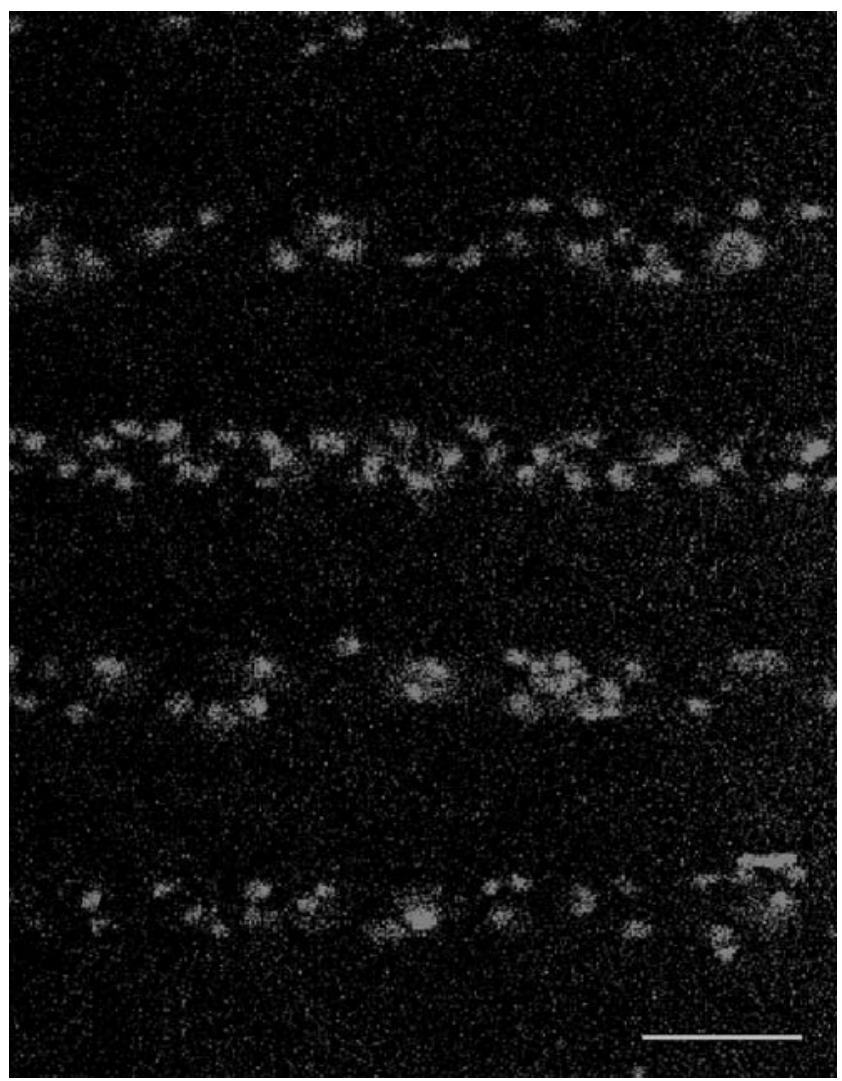

Fig. 1 The distribution of microglia, immunostained with antiCSF-1R, in parallel lanes of width $20 \mu \mathrm{m}$ and separation $45 \mu \mathrm{m}$; the calibration bar is $45 \mu \mathrm{m}$ 
previously prepared microchannels and then incubated for $15 \mathrm{~min}$. Incubating DMEM was replaced with fresh DMEM containing $50 \%$ of spinal cord astrocytic conditioned medium (ACM). After $15 \mathrm{~min}$, microglia selectively adhere to the poly-D-lysine coating whereas other cell types that may be present, such as any remaining astrocytes and oligodendrocytes, take a longer period of time to adhere [29]. The purity of the microglial cultures was greater than $98 \%$ according to live staining of the cells with the microglial marker FITCIB4 (Invitrogen). Microglia-plated microchannels were incubated in ACM supplemented DMEM for $48 \mathrm{~h}$ before use in experiments (Fig. 1). The medium was removed and replaced daily.
For $\mathrm{Ca}^{2+}$ recording, the relative fluorescence amplitude $(\Delta F / F)$, was calculated using the formula

$$
\left(\frac{\Delta F}{F}\right)=\frac{F-\bar{F}_{0}}{\bar{F}_{0}-\bar{F}_{\text {background }}}
$$

where $F$ is the fluorescent intensity during the $\mathrm{Ca}^{2+}$ transient, $\bar{F}_{0}$ is the intensity averaged over the interval immediately before the calcium transient and $\bar{F}_{\text {background }}$ is the average fluorescence intensity measured in several cell-free areas. $\mathrm{Ca}^{2+}$ transients with a maximum $\Delta F / F$ value less than 0.3 (being $15 \%$ of the largest $\mathrm{Ca}^{2+}$ transient observed in a lane of microglia) were discounted as being too close to the noise level
Fig. 2 The $\mathrm{Ca}^{2+}$ wave propagates along a lane of microglia with decreasing amplitude from the point of initiation. $\mathbf{A}$ and $\mathbf{B}$ show results for two different lanes of microglia, of widths $82 \pm 5 \mu \mathrm{m}$ and $38 \pm 4 \mu \mathrm{m}$, respectively. In each case, (a) shows the site of $\mathrm{Ca}^{2+}$ initiation by mechanical stimulation with a micropipette and (b) shows the microglia that responded with a $\mathrm{Ca}^{2+}$ transient (indicated by open circles) after stimulation at the site indicated by the arrow; the calibration bar is $45 \mu \mathrm{m}$. C shows the timecourse of the $\mathrm{Ca}^{2+}$ wave at different distances along a lane from the site of initiation, as indicated. The mechanical stimulus was applied for $1 \mathrm{~s}$ starting at time zero
A

a

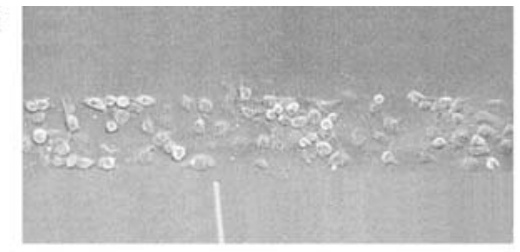

b

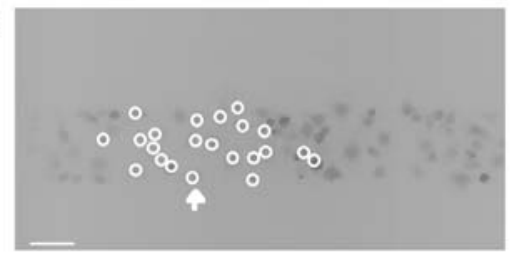

B

a

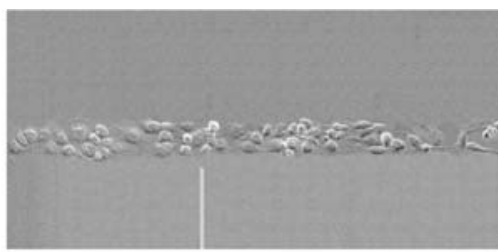

b

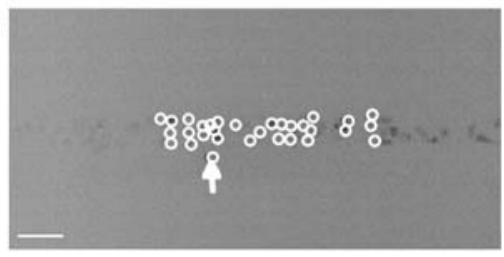

C

a
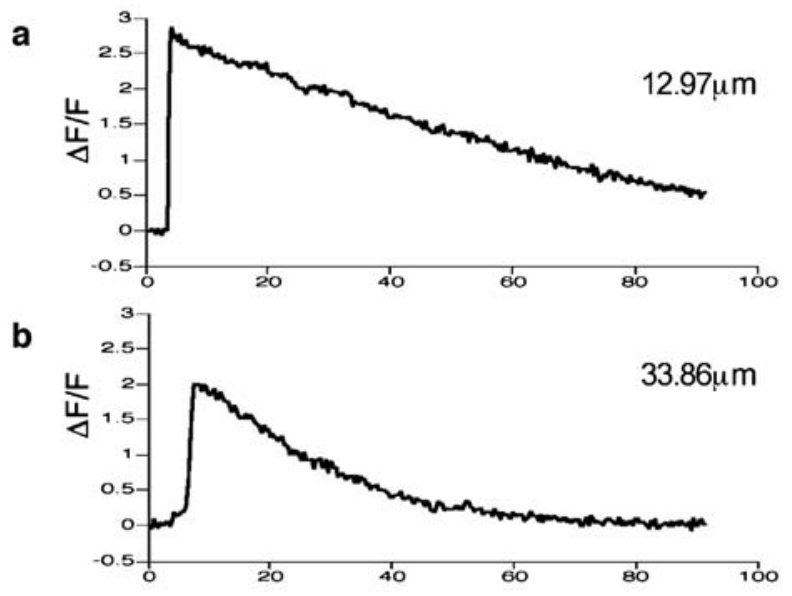

c

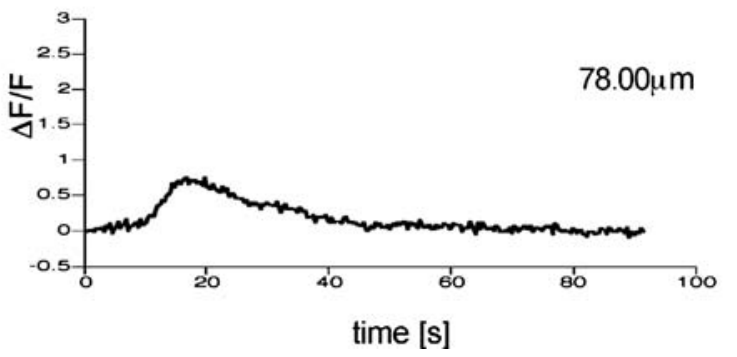



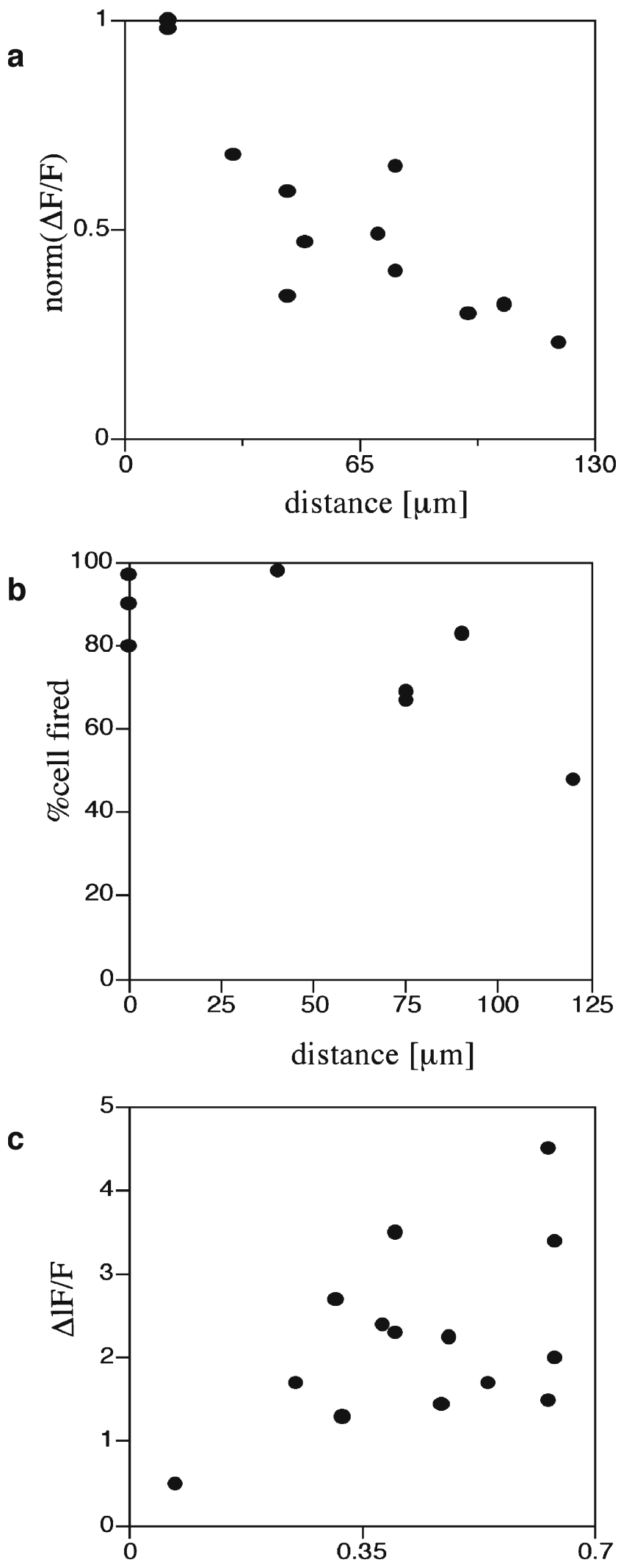

Number of cells fired $/ 10^{3} \mu \mathrm{m}^{2}$
Fig. 3 Quantitative characteristics of the $\mathrm{Ca}^{2+}$ wave for a number of microglia lanes. a shows the average peak amplitude of $\mathrm{Ca}^{2+}$ deliveries along the lanes before becoming undetectable at about $120 \mu \mathrm{m}$ (values normalized to the peak $\mathrm{Ca}^{2+}$ concentration at the stimulating electrode). $\mathbf{b}$ shows the number of microglia that give a $\mathrm{Ca}^{2+}$ response at different positions along the length of a lane, expressed as a percentage of the total number of $\mathrm{Ca}^{2+}$ indicator-labeled microglia at that position; this remains high for about $80 \mu \mathrm{m}$ and then declines. c shows that the average amplitude of the peak $\mathrm{Ca}^{2+}$ wave in equal-width segments of a microglia lane increases with the number of microglia that propagate $\mathrm{Ca}^{2+}$ in the segment. Results in $\mathrm{a}, \mathrm{b}$ and $\mathrm{c}$ are for three different lanes in three different cultures. In $a$ and $b$ the distance is from equal-width segments along a lane (for which the average peak $\mathrm{Ca}^{2+}$ was calculated for all microglia in the segment) to the site of mechanical initiation of the $\mathrm{Ca}^{2+}$ wave

to be reliable. All experiments were repeated at least three times and values are presented as mean \pm s.d. Statistical significance was determined with the use of unpaired $t$-tests and ANOVA, and $P<0.05$ was considered significant. All P2Y receptor antagonists were obtained from TOCRIS.

\section{Mathematical model}

A detailed description of a mathematical model of purinergic transmission in glial networks was given in [28] and subsequently applied to experimental results on such transmission between astrocytes [5]. This model has been adapted to the present case of microglial networks. The basic model is the same, so here we give only a brief summary of the main features, highlighting the changes that have been made.

Communication between the model microglia is mediated by ATP diffusing in the extracellular space. This ATP binds reversibly to metabotropic receptors (P2Y)

Fig. 4 Propagation of a $\mathrm{Ca}^{2+}$ wave occurs between microglial lanes if these are not separated by distances greater than about $60 \mu \mathrm{m}$. A and $\mathbf{B}$ show parallel lanes of microglia in which the lane widths are $75 \pm 3 \mu \mathrm{m}$ and $25 \pm 3 \mu \mathrm{m}$ respectively, separated by cell-free lanes of $165 \pm 3 \mu \mathrm{m}$ and $70 \pm 4 \mu \mathrm{m}$ respectively; the open circles indicate the microglia that gave a $\mathrm{Ca}^{2+}$ response following mechanical excitation of the microglial cell indicated by the arrow; there is no propagation of the $\mathrm{Ca}^{2+}$ wave across these lanes. $\mathbf{C}$ shows parallel lanes of microglia in which lane widths are $50 \pm 6 \mu \mathrm{m}$ and the cell-free lane $46 \pm 10 \mu \mathrm{m}$; the open circles indicate that a $\mathrm{Ca}^{2+}$ wave response was able to propagate across cell-free lanes as well as along the lanes. The calibration bar is 45 $\mu \mathrm{m}$ in $\mathrm{A}, \mathrm{B}$ and $\mathrm{C}$. The position of the micropipette in $\mathrm{C}(\mathrm{a})$ is not evident as it is out of focus 
A

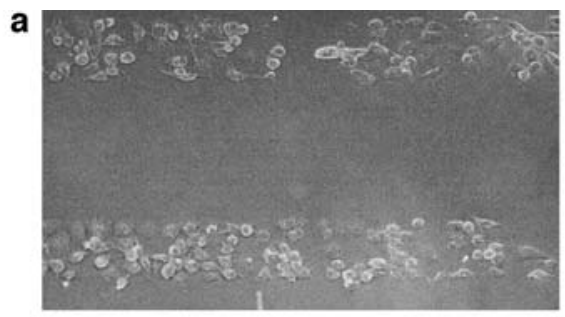

b

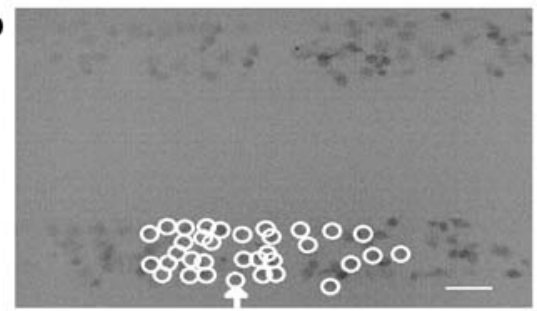

B

a

b
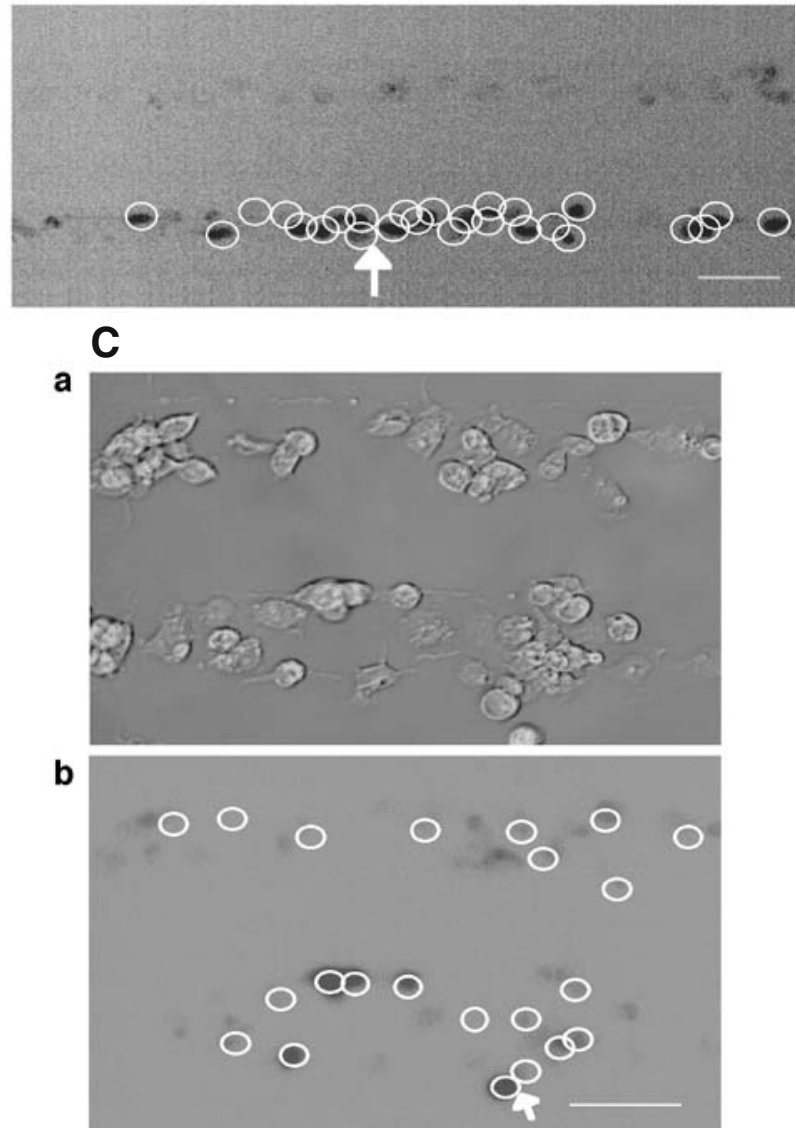

on the surface of cells so that the ratio of bound to total receptors is given by

$\rho=\frac{[A T P]}{K_{R}+[A T P]}$,

where $[A T P]$ is the extracellular ATP concentration and $K_{R}$ is the dissociation constant for ATP binding. The usual meaning of $K_{R}$ is the concentration of ATP at which half the total receptors are bound; however, in the present context $K_{R}$, as well as being a measure of the affinity of receptor types, also reflects additional variables such as spatial variations in receptor density,

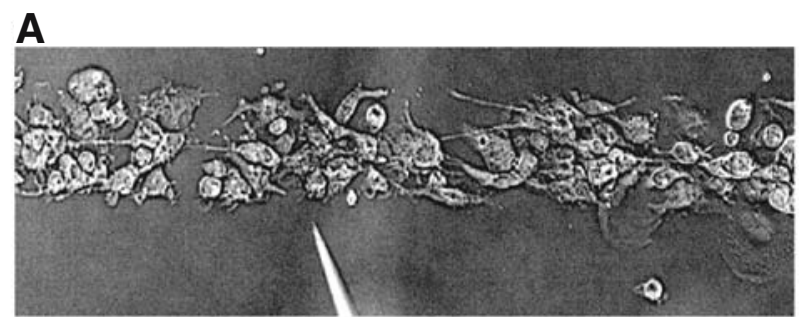

b

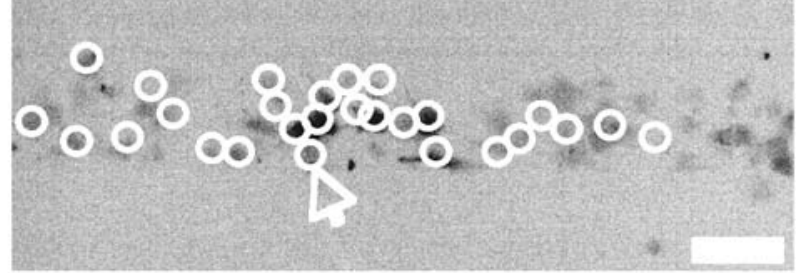

B

a

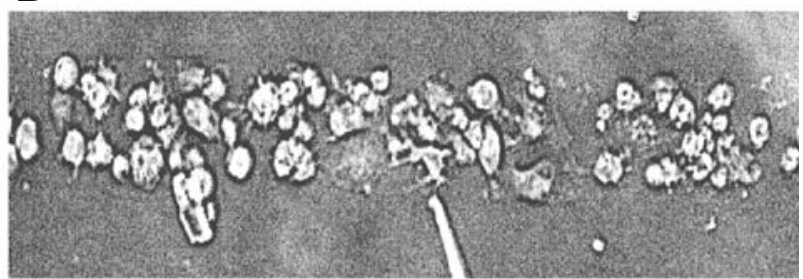

b

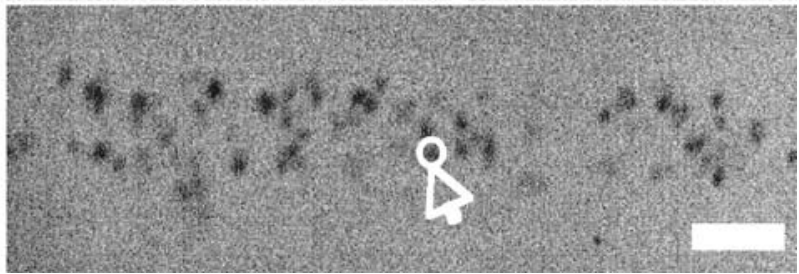

Fig. 5 Propagation of $\mathrm{Ca}^{2+}$ waves is blocked by the ATPdegrading enzyme apyrase. $\mathbf{A}$ and $\mathbf{B}$ show the extent of propagation of $\mathrm{Ca}^{2+}$, from the point of mechanical stimulation of a microglial cell, to other microglial cells in a lane. In each case, the top panel (a) shows the position of the mechanically stimulating micropipette and the lower panel (b) shows the microglial cells that gave a $\mathrm{Ca}^{2+}$ signal (open circles) in response to mechanical stimulation at the arrow. A is the control and in B apyrase (60 units/m $\ell$; grade III, Sigma) was present with only the stimulated cell now giving a $\mathrm{Ca}^{2+}$ transient. The calibration bar is $45 \mu \mathrm{m}$ 


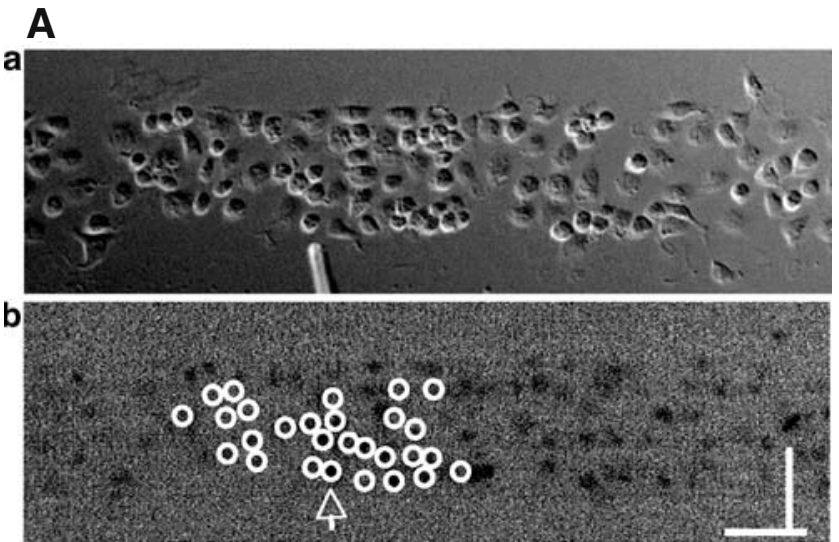

B

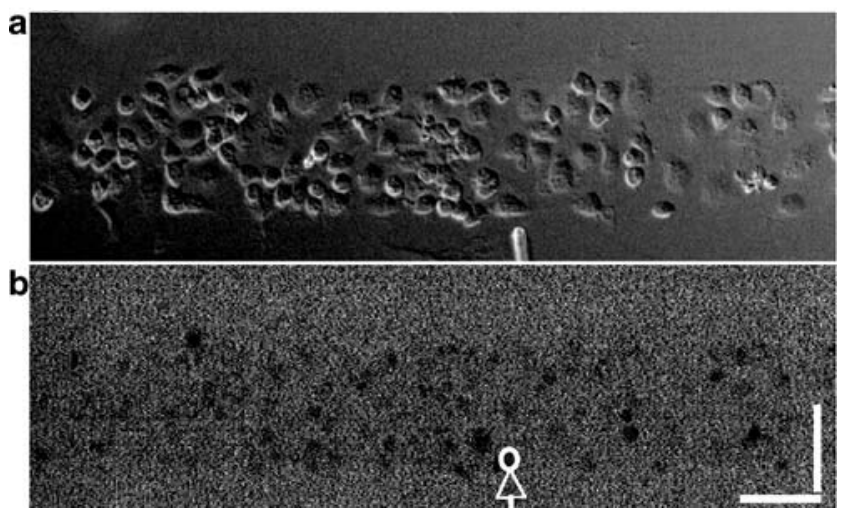

Fig. 6 Transmission of the $\mathrm{Ca}^{2+}$ wave between microglial cells is chemical due to the release of ATP. A and $\mathbf{B}$ show the extent of propagation of $\mathrm{Ca}^{2+}$ from the point of mechanical stimulation of a microglial cell to other microglial cells in a lane. In each case, the top panel ((a)) shows the position of the mechanically stimulating micropipette and the lower panel ((b)) the microglial cell(s) that gave a $\mathrm{Ca}^{2+}$ signal (open circles) in response to mechanical stimulation at the arrow. A is the control and in B suramin $(100 \mu \mathrm{M})$ was present blocking P2Y receptors and only the stimulated cell responded with a $\mathrm{Ca}^{2+}$ transient. The calibration bar is $40 \mu \mathrm{m}$

since $\rho$ is a measure of the effective activity of ATP as a function of space and time. Thus $K_{R}$ is to be interpreted as an effective, rather than an actual, dissociation constant (see the section "Receptors" in [5]).

Each microglial cell is represented by a cube of side $8.3 \mu \mathrm{m}$, and these cubes are arranged in $2 \mathrm{D}$ arrays with their centres $25 \mu \mathrm{m}$ apart. As explained in [28], this simplified geometry does not model the spatial complexity of a real cell, but is a lumped approximation. The $\mathrm{Ca}^{2+}$ wave can be initiated either by increasing the $\mathrm{IP}_{3}$ concentration in a single cell, or by applying ATP extracellularly. In the present calculations, a fixed concentration of ATP (typically $20 \mu \mathrm{M}$ ) is applied for an extended time (typically $5 \mathrm{~s}$ ) to the surface of one model microglial cell. The parameters used are those given in Table 1 of [28], except that the parameter governing the ATP release rate, $V_{\mathrm{ATP}}$, has been reduced from $2 \times 10^{-11}$ to $5 \times 10^{-12} \mu \mathrm{mol} \mu \mathrm{m}^{-2} \mathrm{~s}^{-1}$ in order to obtain agreement with the experimental observations.

\section{Results}

Quantitative characteristics of $\mathrm{Ca}^{2+}$ wave propagation

The amplitude and velocity of propagating $\mathrm{Ca}^{2+}$ waves in microglia at different positions along microglia lanes, from a point of mechanical initiation in a microglia, were determined. Figures $2 \mathrm{~A}$ and $\mathrm{B}$ show the extent of propagation from the point of stimulation in two lanes, $\sim 80 \mu \mathrm{m}$ and $\sim 40 \mu \mathrm{m}$ wide, respectively. The $\mathrm{Ca}^{2+}$ wave propagates with diminution in amplitude (Fig. 2C), at a velocity of about $5 \mu \mathrm{m} \mathrm{s} \mathrm{s}^{-1}$, over a distance of at most $120 \mu \mathrm{m}$ before becoming undetectable. This velocity is about one-quarter of that for $\mathrm{Ca}^{2+}$ wave propagation in astrocyte lanes [5]. Quantitation of these observations for four different sets of microglia lanes in four cultures is shown in Fig. 3. Figure 3a shows that there is a continual decrease in amplitude of the $\mathrm{Ca}^{2+}$ wave over $120 \mu \mathrm{m}$ at which distance the amplitude falls below $15 \%$ to $20 \%$ of the initial amplitude and could no longer be reliably detected. The percentage of microglia cells across a lane that gives a $\mathrm{Ca}^{2+}$ peak amplitude change that is greater than $15 \%$ of the peak amplitude at the site of initiation remains high for about the first $80 \mu \mathrm{m}$ and then declines rapidly over the succeeding $40 \mu \mathrm{m}$ (Fig. 3b). On the other hand, the peak $\mathrm{Ca}^{2+}$ amplitude increases rapidly with an increase in the local density of cells that give an observable $\mathrm{Ca}^{2+}$ transient response (Fig. 3c).

The restricted local propagation of the $\mathrm{Ca}^{2+}$ wave from the point of initiation is emphasized by experiments in which different sites of initiation along a single lane of microglia are determined. As Fig. 2 shows, in each case the $\mathrm{Ca}^{2+}$ wave propagation is restricted to regions of about $100 \mu \mathrm{m}$ diameter around the site of initiation.

Evidence for release and diffusion of ATP during $\mathrm{Ca}^{2+}$ wave propagation

In order to test for the possibility that mechanically stimulated microglial cells release a diffusible substance, parallel lanes of microglia were constructed, separated by cell-free lanes (see Fig. 1). Tests were then made of the extent to which $\mathrm{Ca}^{2+}$ waves could propagate across these cell-free lanes of widths $70 \mu \mathrm{m}$ or more, independent of the width of the microglia lanes (Figs. 4A and B). No such propagation was observed in 
Fig. 7 Density of P2Y

receptors on microglia.

a Distribution of anti-P2 $\mathrm{Y}_{12}$

receptor immunofluorescence

on single spinal-cord

microglia in lanes; the shape

of the cell is given by the

borders of immunohisto-

chemical staining.

b Histogram of the density

of and anti-P2 $\mathrm{Y}_{12}$ labelled

receptors for different

microglia. The error bars

indicate \pm SEM. At least ten

areas on each cell were used to determine the $\mathrm{P} 2 \mathrm{Y}$ receptor density a

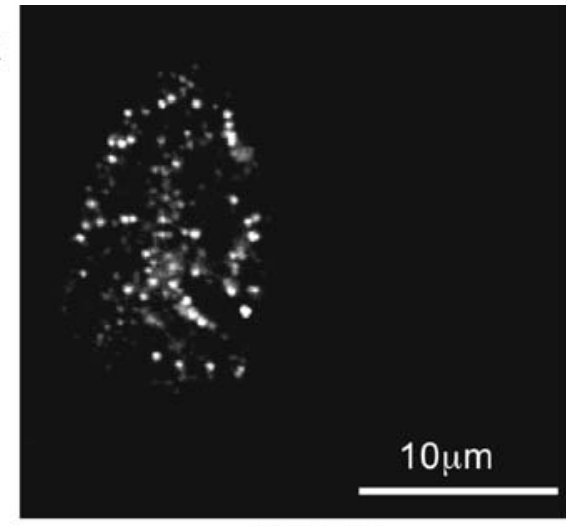

P2Y12

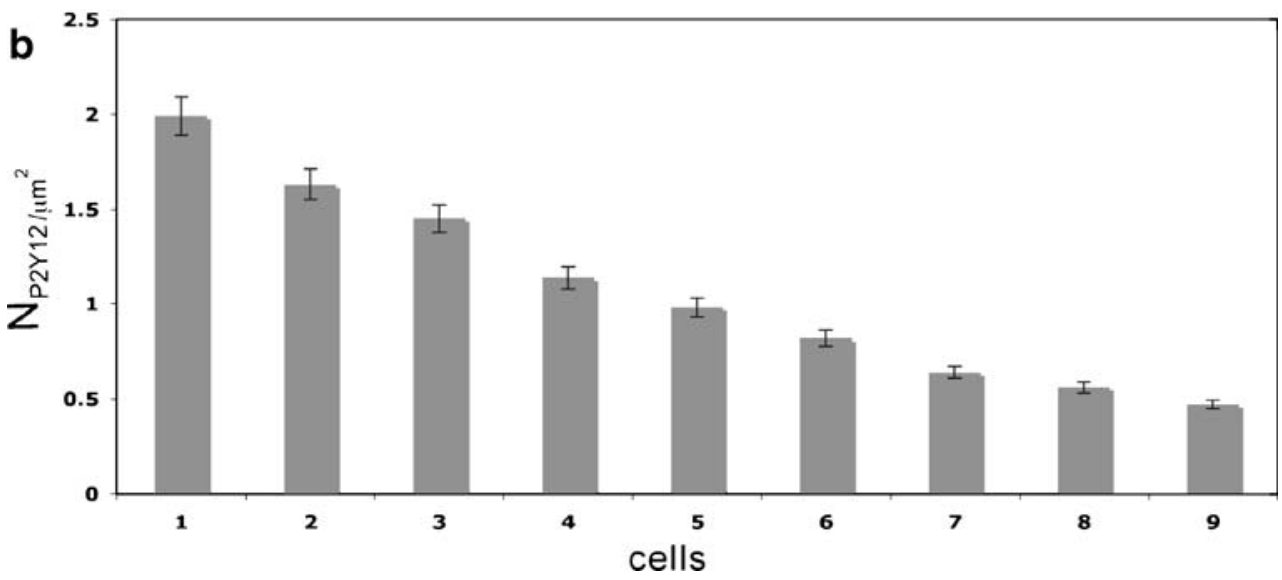

20 experiments. On the other hand, if the cell-free lanes were less than $\sim 60 \mu \mathrm{m}$ wide there was always successful propagation of the $\mathrm{Ca}^{2+}$ wave across the cell-free lanes
(Fig. 4C). It appears then that a diffusible substance is released by the excited microglia and is able to initiate $\mathrm{Ca}^{2+}$ transients in them.
Fig. 8 Diagrammatic representation of the theoretical spatial and temporal changes in a $\mathrm{Ca}^{2+}$ wave in a lane of microglia five cells wide following excitation of the central microglia, according to the mathematical model. The $\mathrm{Ca}^{2+}$ wave is initiated by a $5-\mathrm{s}$ pulse of ATP of concentration $20 \mu \mathrm{M}$. The vertical bars give $\mathrm{Ca}^{2+}$ in $\mu \mathrm{M}$ at times $\mathrm{t}=7.5,15,22.5$ and $30 \mathrm{~s}$, as indicated. $K_{R}$ values range from 25 to $45 \mu \mathrm{M}$ for different microglia across each lane
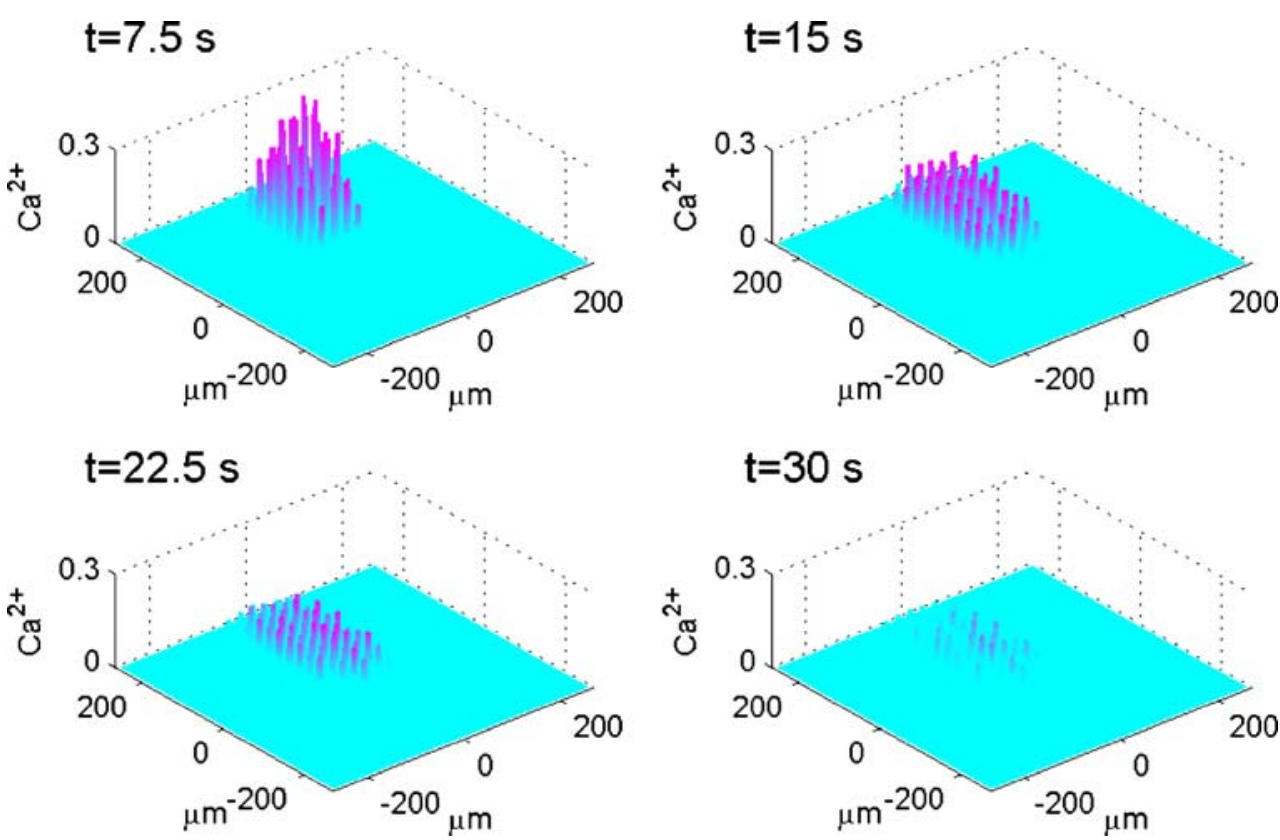

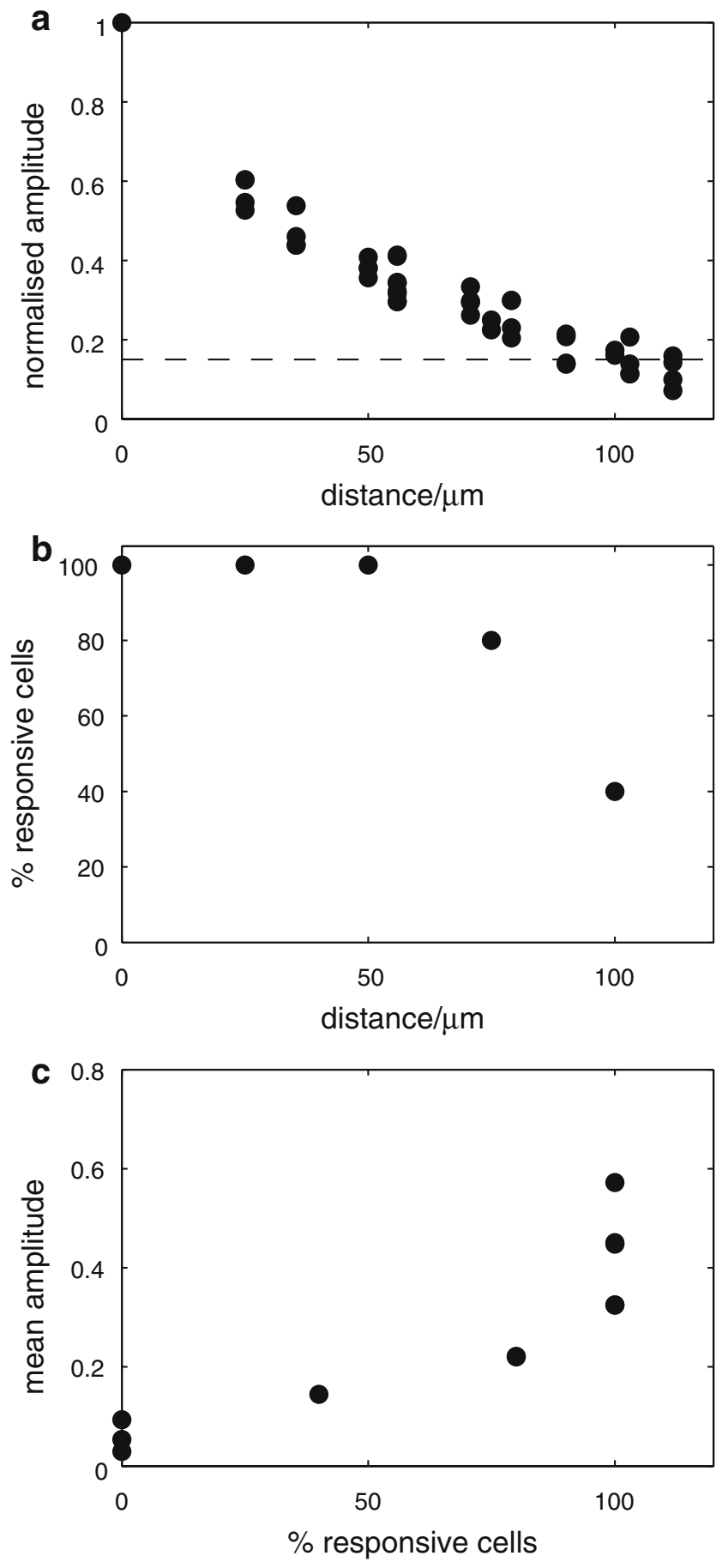

Since astrocytes use ATP as a chemical transmitter, and it is known that microglia initiate $\mathrm{Ca}^{2+}$ transients in response to ATP, we determined if ATP was likely to be the diffusible substance released by microglia in order to promote $\mathrm{Ca}^{2+}$ wave propagation. First, $\mathrm{Ca}^{2+}$ wave propagation was blocked by the ATP-degrading enzyme apyrase (grade III, 60 units per $\mathrm{m} \ell$; Fig. 5). Second, the effects of antagonists to the P2Y class of purinergic receptors on $\mathrm{Ca}^{2+}$ wave propagation were
Fig. 9 Theoretical characteristics of a $\mathrm{Ca}^{2+}$ wave in a microglia lane, according to the mathematical model as in Fig. 8, for quantitative comparison with the observed characteristics (see Fig. 3). a shows that the predicted peak amplitude of $\mathrm{Ca}^{2+}$ for all cells in a lane, normalized to that at the site of stimulation, declines with distance along the length of the lane until it becomes undetectable at about $120 \mu \mathrm{m}$ (compare to Fig. 3a); the horizontal line indicates the values of the $\mathrm{Ca}^{2+}$ amplitude below which experimental detection is in the noise level (set at $15 \%$ ). b shows the predicted number of microglia that give a $\mathrm{Ca}^{2+}$ response greater than $15 \%$ of the maximum value at different positions along the length of a lane expressed as a percentage of the total number of cells at that position; this is maintained for about $70 \mu \mathrm{m}$ and then declines rapidly (compare to Fig. 3b). c shows that the predicted amplitude of the average peak $\mathrm{Ca}^{2+}$ in rows of a microglia lane increases with the number of microglia that propagate $\mathrm{Ca}^{2+}$ in the row (compare to Fig. 3c)

tested. It is known that the pharmacological profile of $\mathrm{P} 2 \mathrm{Y}$ receptor activation on spinal cord microglia and the expression of their mRNA clearly favours $\mathrm{P} 2 \mathrm{Y}_{12}$ receptors, followed by $\mathrm{P}_{2} \mathrm{Y}_{6}$ and $\mathrm{P}_{2} \mathrm{Y}_{1}$ according to [12] and $\mathrm{P}_{2} \mathrm{Y}_{2}, \mathrm{P}_{2} \mathrm{Y}_{6}, \mathrm{P}_{2} \mathrm{Y}_{12}$ and $\mathrm{P}_{2} \mathrm{Y}_{14}$ according to [14]. Suramin $(100 \mu \mathrm{M})$ completely blocked all propagation of the $\mathrm{Ca}^{2+}$ wave along microglial lanes (compare Fig. 6B with 6A), indicating that $\mathrm{P}_{2} \mathrm{Y}_{6}$ and $\mathrm{P}_{2} \mathrm{Y}_{14}$ are not involved, and this was confirmed for $\mathrm{P}_{2} \mathrm{Y}_{6}$ using the specific $\mathrm{P}_{2} \mathrm{Y}_{6}$ antagonist MRS $2578(30 \mu \mathrm{M})$. The specific P2 $\mathrm{Y}_{1}$ antagonist MRS $2500(100 \mu \mathrm{M})$ did not block the $\mathrm{Ca}^{2+}$ wave. On the other hand, the $\mathrm{P}_{2} \mathrm{Y}_{12}-$ specific antagonist 2-MeSAMP $(300 \mu \mathrm{M})$ blocked $\mathrm{Ca}^{2+}$ wave propagation. Any contribution of $\mathrm{P} 2 \mathrm{X}$ receptors known to be present on microglial cells, such as $\mathrm{P}_{2} \mathrm{X}_{4}$ and $\mathrm{P}_{2} \mathrm{X}_{7}$ [11], to $\mathrm{Ca}^{2+}$ wave propagation is likely to be minimal given the blocking effects of the $\mathrm{P}_{2} \mathrm{Y}_{12}$ specific antagonist 2-MeSAMP. We conclude that $\mathrm{Ca}^{2+}$ wave propagation between microglial cells involves the release of ATP onto at least $\mathrm{P}_{2} \mathrm{Y}_{12}$ receptors. Visentin et al. [14] have also placed emphasis on the role of $\mathrm{P} 2 \mathrm{Y}_{12}$ receptors in calcium signalling.

\section{Density of P2Y receptors on microglia}

The theoretical requirement that $K_{R}$ take values from 25 to $45 \mu \mathrm{M}$ may reflect different densities of P2Y receptors on the microglia, since in the present theory $K_{R}$ depends on this density as well as on the dissociation of ATP from the receptors (see Theory section above, and also the following section). Polyclonal antibody labelling of $\mathrm{P}^{2} \mathrm{Y}_{12}$ (Fig. 7a) receptors indicated that these are localized in clusters of average diameter 0.45 $\mu \mathrm{m}$, as are $\mathrm{P} 2 \mathrm{Y}$ receptors on astrocytes [5] and smoothmuscle cells [30]. The density of $\mathrm{P}_{2} \mathrm{Y}_{12}$ receptors, measured over nine microglial cells, varied about four-fold (Fig. 7b). We suggest that $\mathrm{P} 2 \mathrm{Y}_{12}$ receptors mediate the 
a

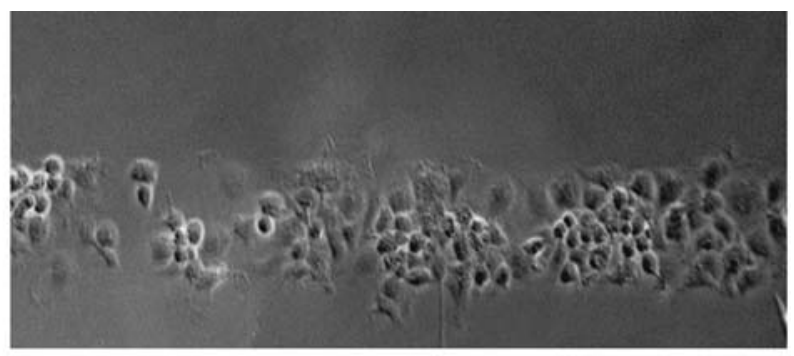

b

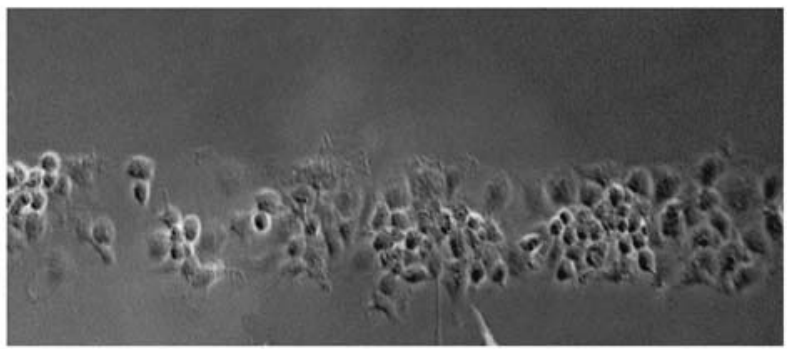

C

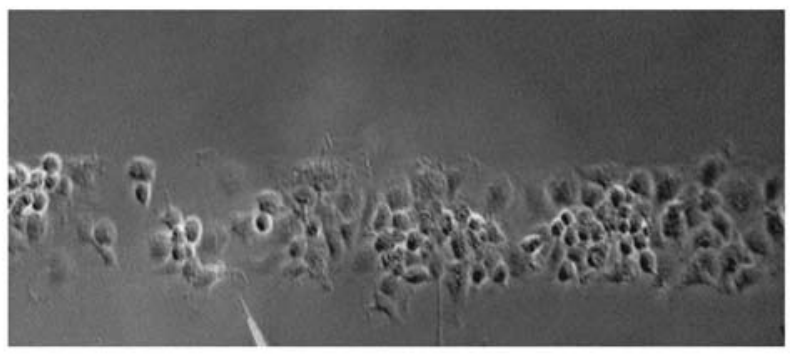

d

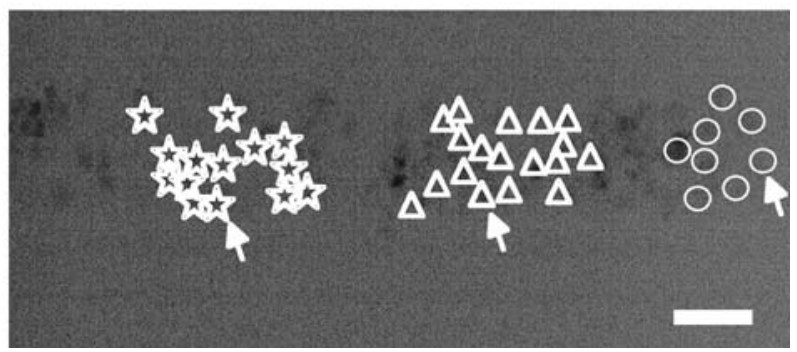

Fig. 10 Stimulation of microglia at different sites in a lane leads to $\mathrm{Ca}^{2+}$ wave propagation confined to the vicinity of the stimulating electrode. Shown in (a), (b) and (c) are three different sites, greater than $140 \mu \mathrm{m}$ apart, of mechanical stimulation by a micropipette of a single cell in a single lane of microglia. In (d) is shown that the $\mathrm{Ca}^{2+}$ waves initiated in each case $((\mathbf{a})$ to $(\mathbf{c}))$ are confined to a region within $90 \mu \mathrm{m}$ of the stimulating micropipette, with each set of symbols indicating the extent of $\mathrm{Ca}^{2+}$ wave propagation. The calibration bar is $45 \mu \mathrm{m}$. The position of the micropipette in $\mathrm{C}(\mathrm{a})$ is not evident as it is out of focus

$\mathrm{Ca}^{2+}$ wave propagation. Since in the present model $K_{R}$ values need to vary over at least a two-fold range, it may be that this variability is partly due to differences in $\mathrm{P} 2 \mathrm{Y}_{12}$ receptor density.

Modelling the quantitative characteristics of $\mathrm{Ca}^{2+}$ wave propagation amongst microglia

The model of purinergic transmission of the $\mathrm{Ca}^{2+}$ wave given in the Methods was used to give a quantitative description for comparison with the experimental results. A lane of microglia five cells wide and $528 \mu \mathrm{m}$ long was considered in which the centre-to-centre distance between the microglia was $25 \mu \mathrm{m}$. The whole lane of microglia was placed on a 2D surface $528 \mu \mathrm{m}$ by $528 \mu \mathrm{m}$ (Fig. 8). Each row of five cells possessed $K_{R}$ values assigned by random permutations of the values $25,30,35,40$ and $45 \mu \mathrm{M}$. Note that these are effective $K_{R}$ values that take into account other properties besides dissociation of ATP from $\mathrm{P} 2 \mathrm{Y}$ receptors. Activation of a microglial cell in the centre of the lane, by increasing the ATP concentration about the cell to $20 \mu \mathrm{M}$ for $5 \mathrm{~s}$, generated a $\mathrm{Ca}^{2+}$ wave that propagated with diminution as shown in Fig. 8 . The $\mathrm{Ca}^{2+}$ wave varied in amplitude and velocity, both across the width of the lane as well as along its length (Fig. 8).

A quantitative analysis of $\mathrm{Ca}^{2+}$ wave propagation in a lane, such as that shown in Fig. 8, gives the results summarised in Fig. 9. The peak amplitude of $\mathrm{Ca}^{2+}$ in each microglial cell of the lane varied significantly both along the length and across the width of the lane (Fig. 9a). Normalizing the $\mathrm{Ca}^{2+}$ to the largest amplitude observed at the site of initiation shows that many of the cells give a $\mathrm{Ca}^{2+}$ amplitude that is less than $15 \%$ of the largest one (Fig. 9a). Using this as a cut-off for the $\Delta \mathrm{F} / \mathrm{F}$ value that would be observed experimentally (see Methods) gives a rate of decline of $\mathrm{Ca}^{2+}$ with distance similar to that observed, from $100 \%$ to $20 \%$ over about $120 \mu \mathrm{m}$ (compare Fig. 9a with Fig. 3a). The percentage of cells that gives a $\mathrm{Ca}^{2+}$ amplitude greater than $15 \%$ of the largest amplitude at the site of initiation, for different rows of five cells along the length of the lane, remains high for the first $75 \mu \mathrm{m}$ and then declines to about $40 \%$ of maximum at $120 \mu \mathrm{m}$. This is a similar pattern of $\mathrm{Ca}^{2+}$ changes to that observed experimentally along a lane of microglia (compare Fig. 9b with Fig. 3b). The average amplitude of the peak $\mathrm{Ca}^{2+}$ across rows of cells in a lane increases with the number of cells that are activated in a row (Fig. 9c). This is also observed experimentally (compare Fig. 9c with Fig. 3c).

These theoretical results highlight the fact that $\mathrm{Ca}^{2+}$ wave propagation amongst microglial cells is very limited compared with that amongst astrocytes [5]. Experimentally, this was highlighted by mechanical stimulation of microglial cells at different well-separated sites along a single microglial lane, showing that $\mathrm{Ca}^{2+}$ wave propagation was restricted to within about $90 \mu \mathrm{m}$ of the stimulating micropipette (see Fig. 10). Such restricted propagation was also observed along the model lane following stimulation at well-separated sites (compare Fig. 11 with Fig. 10). The clustering of activated cells near the site of initiation of the $\mathrm{Ca}^{2+}$ wave is, in the 


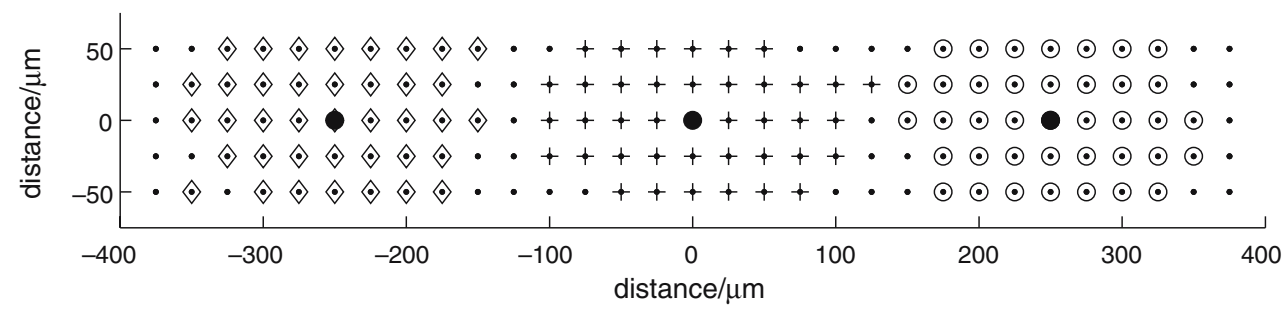

Fig. 11 Theoretical predictions of the distribution of microglia in a lane five cells wide that gave a $\mathrm{Ca}^{2+}$ response, with an amplitude greater than $15 \%$ of maximum, following excitation of a single microglial cell at three different sites along the length of the lane, indicated by filled circles $(\bullet)$. The dots indicate the positions of microglia in the lane. The diamonds $(\diamond)$ indicate microglia that gave a response following stimulation of the microglia near the left-hand end of the lane (sixth cell from the left at $-250 \mu \mathrm{m}$ ), the

model, due to the large amount of ATP released in this region.

The model of purinergic transmission of $\mathrm{Ca}^{2+}$ waves was used to see if it could account for $\mathrm{Ca}^{2+}$ propagation along and between lanes of microglia, such as those shown in Fig. 4. Figure 12 shows the propagation of $\mathrm{Ca}^{2+}$ waves in three such parallel lanes of cells, separated by cell-free lanes $42 \mu \mathrm{m}$ wide, following initiation of the $\mathrm{Ca}^{2+}$ wave in the middle row of the middle lane by applying $20 \mu \mathrm{M}$ of ATP for $5 \mathrm{~s}$ at a central cell. There is propagation of the $\mathrm{Ca}^{2+}$ wave over about six cells of the middle lane before the side lanes are engaged, at about $7 \mathrm{~s}$ after application of the initiating stimulus
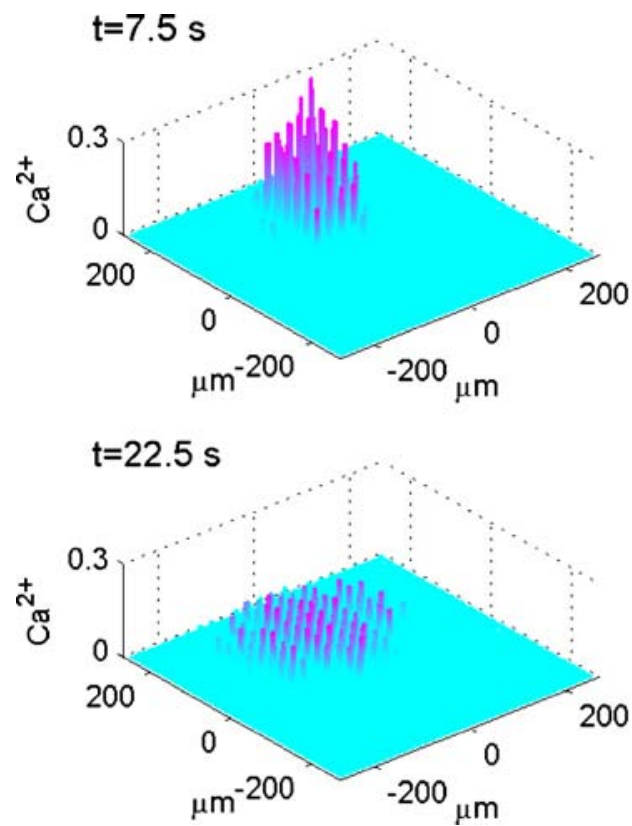

Fig. 12 A diagrammatic representation of the theoretical spatial and temporal changes in $\mathrm{Ca}^{2+}$ in three lanes of microglia each five cells wide, separated by cell-free lanes $42 \mu \mathrm{m}$ wide, following excitation of a single microglial cell in the middle row of the middle lane. The $\mathrm{Ca}^{2+}$ wave is initiated by a 5 -s pulse of ATP of open circles (o) responses following stimulation of the microglia near the right-hand end of the lane (sixth cell from the right at $250 \mu \mathrm{m}$ ) and the plusses (+) microglia in the centre of the lane $($ at $0 \mu \mathrm{m})$. (A longer lane $(800 \mu \mathrm{m})$ has been used for this calculation.) The $K_{R}$ values range from 25 to $45 \mu \mathrm{M}$ for different microglia across each lane. Note that there is no overlap in the $\mathrm{Ca}^{2+}$ wave domains of each stimulated microglial cell, the diamonds, crosses and circles designating discrete regions

(Fig. 12). Both side lanes first generate a $\mathrm{Ca}^{2+}$ wave that is in cells in a row opposite or nearly opposite the row containing the initiating cell in the middle lane. By $13 \mathrm{~s}$ the crest of the $\mathrm{Ca}^{2+}$ wave has reached the limits of $\mathrm{Ca}^{2+}$ propagation at about $100 \mu \mathrm{m}$ from the site of initiation, by which time it has travelled less than $75 \%$ of that distance along adjacent lanes (Fig. 12). Very few cells are engaged in $\mathrm{Ca}^{2+}$ wave propagation in these adjacent lanes and propagation fails over distances of about $70 \mu \mathrm{m}$ along the lane and $50 \mu \mathrm{m}$ across it.

The question arises as to whether regeneration of ATP in each cell is necessary. Repeating calculations with regenerative release switched off, and thus only
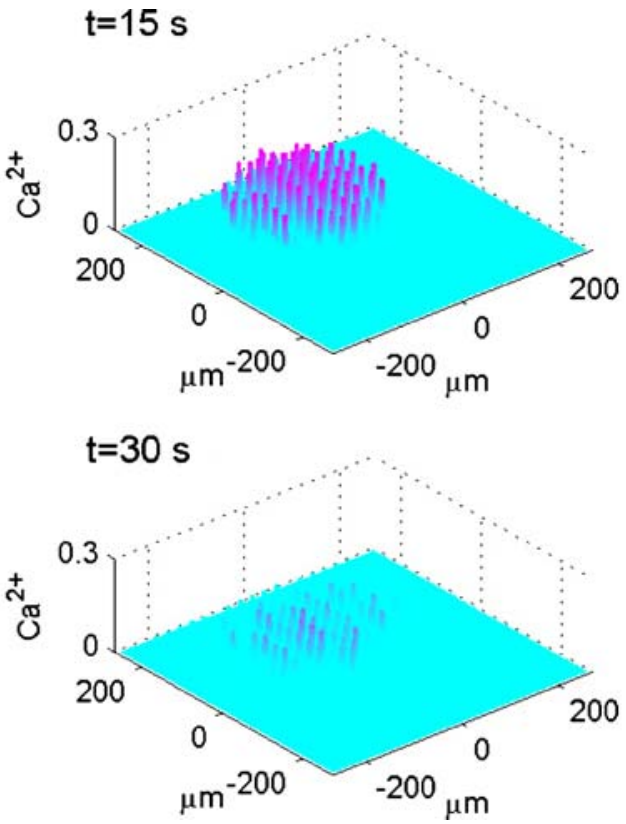

concentration $20 \mu \mathrm{M}$ on the central microglial cell at time $t=0$. The vertical bars give $\mathrm{Ca}^{2+}$ in $\mu \mathrm{M}$ at times $\mathrm{t}=7.5,15,22.5$ and 30 s, as indicated. $K_{R}$ values range from 25 to $45 \mu \mathrm{M}$ for different microglia across each lane. Note the limited propagation of the $\mathrm{Ca}^{2+}$ wave in both the middle and side lanes 
pure diffusion of ATP from its initial release site, gave travel distances along lanes reduced by about $20 \%$. We investigated whether this reduced distance could be compensated for by increasing the initial release of ATP, but this then recruited cells in adjacent lanes in a way not observed experimentally. Thus the theoretical calculations indicate a role for intracellular regeneration of ATP, but at a much lower rate than in astrocytes.

\section{Discussion}

Although activation of $\mathrm{P} 2 \mathrm{X}_{7}$ receptors by ATP leads to an influx of calcium ions in microglial cells [16, 31-33] it does not seem that these receptors mediate the $\mathrm{Ca}^{2+}$ wave propagation in these cells as this is blocked by suramin which does not block $\mathrm{P} 2 \mathrm{X}_{7}$ receptors. It seems likely that $\mathrm{P} 2 \mathrm{X}_{7}$ receptors are activated at higher concentrations of ATP than is required for P2Y receptor activation [33], suggesting that the concentration of ATP reached at the receptors after its release from microglia is insufficient to excite $\mathrm{P}_{2} \mathrm{X}_{7}$ receptors. ATP acts on microglial cells to both release calcium from internal stores and to evoke an influx of calcium [34, 35]. P2Y receptors mediate $\mathrm{Ca}^{2+}$ release from internal stores in microglial cells $[14,21,32,33,36,37]$, the extent of this release being under the modulatory control of $\mathrm{P} 2 \mathrm{X}$ receptors [25, 32] and of toll-like receptors [38].

ATP released following stimulation of astrocytes can generate $\mathrm{Ca}^{2+}$ transients in nearby microglial cells [2]. Repeated stimulation of the astrocytes releases sufficient ATP to activate $\mathrm{P} 2 \mathrm{X}_{7}$ receptors on the microglial cells, greatly increasing membrane permeability in the microglial cells [1] and leading to the release of inflammatory cytokines, such as IL-2, from the cells [39]. The present work suggests that in these experiments the ATP released in moderate amounts from singly stimulated astrocytes most likely acts on $\mathrm{P}_{2} \mathrm{Y}_{12}$ receptors on microglial cells. We could block the ATP-dependent $\mathrm{Ca}^{2+}$ propagation in these cells with suramin, which blocks $\mathrm{P} 2 \mathrm{Y}_{1}, \mathrm{P}_{2} \mathrm{Y}_{2}$ and $\mathrm{P} 2 \mathrm{Y}_{12}$ receptors, but could not be blocked by $\mathrm{P}_{2} \mathrm{Y}_{1}$ receptor antagonists. Given that the predominant receptor on microglial spinal cord cells shows the pharmacological profile of $\mathrm{P}^{2} \mathrm{Y}_{12}$ [12] (see also [14]), we conclude that this receptor, which we found in relatively high density, is most likely to be mediating the effect of ATP. Thus there is no evidence that $\mathrm{P}_{2} \mathrm{X}_{7}$ receptors are engaged in $\mathrm{Ca}^{2+}$ propagation in microglia. It is interesting to note in this regard that microglial cells rapidly re-orientate their processes towards a site of ATP release in vivo as a consequence of the action of the released ATP on P2Y receptors, an action that is blocked by apyrase [40] and that nucleotides acting on $\mathrm{P}_{2} \mathrm{Y}_{12}$ receptors of microglia exert a chemotactic effect [41].

We have used soft lithography techniques of microfabrication to allow controlled and discrete patterning of microglia so that quantitative investigations can be carried out [42]. Such an approach avoids the difficulties inherent in the random seeding of microglial cells on a homogeneous substrate for carrying out quantitative measurements of the properties of propagating calcium waves [43]. The technique allows lanes of microglial cells with controlled widths of from $15 \mu \mathrm{m}$ to over $150 \mu \mathrm{m}$, separated by cell-free regions with the same range of widths [44]. It is unlikely that this fabrication method affects the seeded microglial cells, since when applied to astrocytes the rates of propagation of the $\mathrm{Ca}^{2+}$ waves remain about the same as determined in random seeded cultures $[4,5]$.

The amplitude of the $\mathrm{Ca}^{2+}$ wave, and the percentage of microglial cells excited to give a $\mathrm{Ca}^{2+}$ response, were correlated along the length of a microglial lane, both decreasing from near the site of initiation over a distance of about $120 \mu \mathrm{m}$ before the wave ceased to be detectable. Decreases in amplitude of $\mathrm{Ca}^{2+}$ waves from a site of mechanical initiation have often been observed in randomly seeded astrocytes over a homogeneous substrate, but in this case over several hundred microns [45-47]. The purinergic gliotransmission model suggests that the decline in amplitude of the $\mathrm{Ca}^{2+}$ wave is due to the relatively high level of ATP released from the stimulated microglial cell, which then dominates the concentration profile of ATP within approximately $100 \mu \mathrm{m}$. The decline in amplitude of the wave approximately follows this concentration gradient of ATP. The decline in the percentage of microglial cells excited to give a $\mathrm{Ca}^{2+}$ response within this $100 \mu \mathrm{m}$ range is then attributed to a failure of microglial cells possessing a relatively high $K_{R}$ to generate a $\mathrm{Ca}^{2+}$ response as the concentration of ATP declines over the same range. The more than two-fold range in the $K_{R}$ values used in our model is comparable to the range of $\mathrm{P}_{2} \mathrm{Y}_{12}$ receptor densities found in microglial cells using immunohistochemistry.

Our work shows that there can be propagation of $\mathrm{Ca}^{2+}$ waves between parallel lanes of microglial cells when these are about $30 \mu \mathrm{m}$ wide and separated by cell-free lanes about $40 \mu \mathrm{m}$ wide, but this does not occur until many microglial cells in the initiating lane undergo a $\mathrm{Ca}^{2+}$ response. It seems likely that a certain minimum amount of ATP must be released from the initiating lane, involving a certain minimum number of microglial cells undergoing a $\mathrm{Ca}^{2+}$ response, before nearby microglial lanes are excited. Since ATP can diffuse across cell-free lanes as wide as $150 \mu \mathrm{m}$ from 
astrocyte-seeded lanes [5], it seems likely that the ATP released from microglial cells is much less than that from astrocytes since the $\mathrm{P}_{2} \mathrm{Y}_{12}$ receptors in the model for microglia possessed lower $K_{R}$ values $(25-45 \mu \mathrm{M})$ than in the model for astrocytes $(25-125 \mu \mathrm{M}$; [5]).

The purinergic transmission model can account for the observed extent of the $\mathrm{Ca}^{2+}$ wave provided pure diffusion of ATP from the stimulation site is supplemented by regenerative release of ATP from the microglia. Fluctuations in the density of excited microglia along a lane leads to local fluctuations in the amplitude of the $\mathrm{Ca}^{2+}$ wave due to changes in the local ATP concentration, consequential on the changes in the local number of microglial cells excited. This is modelled by assigning a range of $K_{R}$ values to the $\mathrm{P} 2 \mathrm{Y}$ receptors on the microglia, and this also reflects the density of receptors on individual microglial cells.

Stimulation of three different microglial cells some hundreds of microns apart gave a $\mathrm{Ca}^{2+}$ response in microglia at highest density closest to the site of stimulation. Our model quantitatively explains these observations as arising from the large amount of ATP released by the stimulated microglial cell diffusing to activate microglia within about $100 \mu \mathrm{m}$.

Acknowledgements This work was supported by ARC (Australia Research Council) Grant DP0665689.

\section{References}

1. Verderio C, Matteoli M (2001) ATP mediates calcium signaling between astrocytes and microglial cells: modulation by ifn-gamma. J Immunol 166(10):6383-6391

2. Schipke CG, Boucsein C, Ohlemeyer C, Kirchhoff F, Kettenmann H (2002) Astrocyte $\mathrm{Ca} 2+$ waves trigger responses in microglial cells in brain slices. FASEB J 16(2): 255-257

3. Möller T (2002) Calcium signaling in microglial cells. GLIA 40:184-194

4. Takano H, Sul JY, Mazzanti ML, Doyle RT, Haydon PG, Porter MD (2002) Micropatterned substrates: approach to probing intercellular communication pathways. Anal Chem 74(18):4640-4661

5. Bennett MR, Buljan V, Farnell L, Gibson WG (2006) Purinergic junctional transmission and propagation of calcium waves in spinal cord astrocyte networks. Biophys $\mathrm{J}$ 91:3560-3571

6. Hassinger TD, Guthrie PB, Atkinson PB, Bennett MV, Kater SB (1996) An extracellular signaling component in propagation of astrocytic calcium waves. Proc Natl Acad Sci USA 93(23):13268-13273

7. Eugenin EA, Eckardt D, Theis M, Willecke K, Bennett MV, Saez JC (2001) Microglia at brain stab wounds express connexin 43 and in vitro form functional gap junctions after treatment with interferon-gamma and tumor necrosis factoralpha. Proc Natl Acad Sci USA 98(7):4190-4195
8. Graeber MB, Lopez-Redondo F, Ikoma E, Ishikawa M, Imai Y, Nakajima K, Kreutzberg GW, Kohsaka S (1998) The microglia/macrophage response in the neonatal rat facial nucleus following axotomy. Brain Res 813(2):241-253

9. Mittelbronn M, Dietz K, Schluesener HJ, Meyermann R (2001) Local distribution of microglia in the normal adult human central nervous system differs by up to one order of magnitude. Acta Neuropathol 101(3):249-255

10. Ma L, Morton AJ, Nicholson LF (2003) Microglia density decreases with age in a mouse model of Huntington's disease. GLIA 43(3):274-280

11. James G, Butt AM (2002) P2Y and P2X purinoceptor mediated $\mathrm{Ca} 2+$ signalling in glial cell pathology in the central nervous system. Eur J Pharmacol 447(2-3):247-260

12. Light AR, Wu Y, Hughen RW, Guthrie PB (2006) Purinergic receptors activating rapid intracellular $\mathrm{Ca} 2+$ increases in microglia. Neuron Glia Biol 2(2):125-138

13. Bianco F, Fumagalli M, Pravettorsi E, D'Ambrosi N, Volonte C, Matteoli M, Abbracchio MP, Verderio C (2005) Pathophysiological roles of extracellular nucleotides in glial cells: differential expressions of purinergic receptors in resting and activated microglia. Brains Res Rev 48:144-156

14. Visentin S, De Nuccio C, Bellenchi GC (2006) Different patterns of $\mathrm{Ca}^{2+}$ signals are induced by low compared to high concentrations of P2Y agonists in microglia. Purinergic Signalling 2:605-617

15. Sasaki Y, Hoshi M, Akazawa C, Nakamura Y, Tsuzuki H, Inoue K, Kohsaka S (2003) Selective expression of Gi/ocoupled ATP receptor P2Y12 in microglia in rat brain. Glia 44(3):242-250

16. Boucsein C, Zacharias R, Farber K, Pavlovic S, Hanisch UK, Kettenmann H (2003) Purinergic receptors on microglial cells: functional expression in acute brain slices and modulation of microglial activation in vitro. Eur $\mathrm{J}$ Neurosci 17(11):2267-2276

17. Wilson HL, Francis SE, Dower SK, Crossman DC (2004) Secretion of intracellular IL-1 receptor antagonist (type 1) is dependent on $\mathrm{P} 2 \mathrm{X} 7$ receptor activation. J Immunol 173(2):1202-1208

18. Hide I, Tanaka M, Inoue A, Nakajima K, Kohsaka S, Inoue K, Nakata Y (2000) Extracellular ATP triggers tumor necrosis factor-alpha release from rat microglia. J Neurochem 75(3):965-972

19. Suzuki T, Hide I, Ido K, Kohsaka S, Inoue K, Nakata Y (2004) Production and release of neuroprotective tumor necrosis factor by $\mathrm{P} 2 \mathrm{X} 7$ receptor-activated microglia. J Neurosci 24(1):1-7

20. Seo DR, Kim KY, Lee YB (2004) Interleukin-10 expression in lipopolysaccharide-activated microglia is mediated by extracellular ATP in an autocrine fashion. Neuroreport 15(7):1157-1161

21. Möller T, Kann O, Verkhratsky A, Kettenmann H (2000) Activation of mouse microglial cells affects $\mathrm{P} 2$ receptor signaling. Brain Res 853(1):49-59

22. Ferrari D, Villalba M, Chiozzi P, Falzoni S, RicciardiCastagnoli P, Di Virgilio F (1996) Mouse microglial cells express a plasma membrane pore gated by extracellular ATP. J Immunol 156(4):1531-1539

23. Toescu EC, Möller T, Kettenmann H, Verkhratsky A (1998) Long-term activation of capacitative $\mathrm{Ca} 2+$ entry in mouse microglial cells. Neuroscience 86(3):925-935

24. Morigiwa K, Quan M, Murakami M, Yamashita M, Fukuda Y (2000) P2 purinoceptor expression and functional changes of hypoxia-activated cultured rat retinal microglia. Neurosci Lett 282(3):153-156 
25. Wang X, Kim SU, van Breemen C, McLarnon JG (2000) Activation of purinergic $\mathrm{P} 2 \mathrm{X}$ receptors inhibits $\mathrm{p} 2 \mathrm{y}$-mediated $\mathrm{Ca} 2+$ influx in human microglia. Cell Calcium 27(4):205-212

26. Wang Z, Haydon PG, Yeung ES (2000) Direct observation of calcium-independent intercellular ATP signaling in astrocytes. Anal Chem 72(9):2001-2007

27. Ballerini P, Di Iorio P, Ciccarelli R, Nargi E, D'Alimonte I, Traversa U, Rathbone MP, Caciagli F (2002) Glial cells express multiple binding cassette proteins which are involved in ATP release. Neuroreport 13(14):1789-1792

28. Bennett MR, Farnell L, Gibson WG (2005) A quantitative model of purinergic junctional transmission of calcium waves in astrocyte networks. Biophys J 89(4):2235-250

29. Dobrenis K (1998) Microglia in cell culture and in transplantation therapy for central nervous disease. Methods 16(3):320-344

30. Lemon G, Brockhausen J, Li G-H, Gibson WG, Bennett MR (2005) Calcium mobilization and spontaneous transient outward current characteristics upon agonist activation of P2Y2 receptors in smooth muscle cells. Biophys J 88:1507-1523

31. Takenouchi T, Ogihara K, Sato M, Kitani H (2005) Inhibitory effects of U73122 and U73343 on Ca2+ influx and pore formation induced by the activation of $\mathrm{P} 2 \mathrm{X} 7$ nucleotide receptors in mouse microglial cell line. Biochim Biophys Acta 1726(2):177-186

32. McLarnon JG (2005) Purinergic mediated changes in $\mathrm{Ca} 2+$ mobilization and functional responses in microglia: effects of low levels of ATP. J Neurosci Res 81(3):349-356

33. Visentin S, Renzi M, Frank C, Greco A, Levi G (1999) Two different ionotropic receptors are activated by ATP in rat microglia. J Physiol 519(3):723-736

34. McLarnon JG, Zhang L, Goghari V, Lee YB, Walz W, Krieger C, Kim SU (1999) Effects of ATP and elevated K+ on $\mathrm{K}+$ currents and intracellular $\mathrm{Ca} 2+$ in human microglia. Neuroscience 91(1):343-352

35. Norenberg W, Langosch JM, Gebicke-Haerter PJ, Illes P (1994) Characterization and possible function of adenosine 5'-triphosphate receptors in activated rat microglia. $\mathrm{Br} \mathrm{J}$ Pharmacol 111(3):942-950

36. Franchini L, Levi G, Visentin S (2004) Inwardly rectifying $\mathrm{K}+$ channels influence $\mathrm{Ca} 2+$ entry due to nucleotide receptor activation in microglia. Cell Calcium 35(5):449-459
37. Choi HB, Hong SH, Ryu JK, Kim SU, McLarnon JG (2003) Differential activation of subtype purinergic receptors modulates $\mathrm{Ca}(2+)$ mobilization and $\mathrm{COX}-2$ in human microglia. GLIA 43(2):95-103

38. Kann O, Hoffmann A, Schumann RR, Weber JR, Kettenmann H, Hanisch UK (2004) The tyrosine kinase inhibitor AG126 restores receptor signaling and blocks release functions in activated microglia (brain macrophages) by preventing a chronic rise in the intracellular calcium level. J Neurochem 90(3):513-525

39. Bianco F, Pravettoni E, Colombo A, Schenk U, Möller T, Matteoli M, Verderio C (2005) Astrocyte-derived ATP induces vesicle shedding and IL-1 beta release from microglia. J Immunol 174(11):7268-7277

40. Davalos D, Grutzendler J, Yang G, Kim JV, Zuo Y, Jung S, Littman DR, Dustin ML, Gan WB (2005) ATP mediates rapid microglial response to local brain injury in vivo. Nat Neurosci 8(6):752-758

41. Nasu-Tada K, Koizumi S, Inoue K (2005) Involvement of $\beta 1$ integrin in microglial chemotaxis and proliferation on fibronectin: different regulations by ADP through PKA. Glia 52(2):98-107

42. Whitesides GM, Ostuni E, Takayama S, Jiang X, Ingber DE (2001) Soft lithography in biology and biochemistry. Annu Rev Biomed Eng 3:335-373

43. Folch A, Toner M (2000) Microengineering of cellular interactions. Ann Rev Biomed Eng 6:41-75

44. Recknor JB, Recknor JC, Sakaguchi DS, Mallapragada SK (2004) Oriented astroglial cell growth on micropatterned polystyrene substrates. Biomaterials 25(14):2753-2767

45. Giaume C, Venance L (1998) Intercellular calcium signaling and gap junctional communication in astrocytes. GLIA 24(1):50-64

46. Blomstrand F, Aberg ND, Eriksson PS, Hansson E, Ronnback L (1999) Extent of intercellular calcium wave propagation is related to gap junction permeability and level of connexin-43 expression in astrocytes in primary cultures from four brain regions. Neuroscience 92(1):255-65

47. Suadicani SO, De Pina-Benabou MH, Urban-Maldonado M, Spray DC, Scemes E (2003) Acute downregulation of Cx43 alters P2Y receptor expression levels in mouse spinal cord astrocytes. GLIA 42(2):160-171 